\title{
Utilizing Platelets as a Targeted for Gene Therapy of Hemophilia a and Hemophilia B
}

Qizhen Shi

Medical College of Wisconsin, Milwaukee, Wisconsin, United States

Hemophilia A is a genetic bleeding disorder resulting from a deficiency of coagulation protein factor VIII (FVIII). FVIII Protein replacement therapy is effective, but up to $30 \%$ of patients will develop inhibitory antibodies (inhibitors) against FVIII, rendering protein replacement treatment useless. Gene therapy is an attractive alternative for the treatment of hemophilia A as it may provide a cure if successful. We have developed a gene therapy protocol in which FVIII expression is ectopically targeted to platelets under control of the platelet-specific $\alpha$ IIb promoter, termed $2 \mathrm{bF} 8$. Using a transgenic mouse model, we have demonstrated that FVIII is stored together with its carrier protein von Willebrand factor (VWF) in platelet $\alpha$-granules as determined by electronic microscopy and confocal microscopy. Our studies have demonstrated that platelet-derived FVIII can rescue the bleeding phenotype in hemophilia A mice even in the presence of high-titers of inhibitors. Our further studies demonstrate that $2 \mathrm{bF} 8$ lentiviral gene delivery to hematopoietic stem cells (HSCs) by HSC transduction followed by syngeneic transplantation can not only effectively restore the hemostasis but also induce antigen-specific immune tolerance in hemophilia A mice. When a similar protocol is applied to hemophilia $\mathrm{B}$, which is a genetic bleeding disorder resulting from a deficiency of factor FIX (FIX), we show that FIX can also be stored in platelet $\alpha$-granules when it is driven by the platelet-specific $\alpha \mathrm{IIb}$ promoter (2bF9) and that platelet-derived FIX can rescue the bleeding phenotype in hemophilia B mice. Unlike platelet-FVIII in hemophilia A mice, the clinical efficacy of platelet-derived FIX is limited in hemophilia B mice in the presence of anti-FIX inhibitors. This could be because FIX does not have a carrier protein to protect it, so inhibitors can freely inactivate functional FIX once it is released from platelets. However, using hyperfunctional 2bF9 gene therapy can eradicate inhibitors and ultimately provide therapeutic protein once inhibitors drop to undetectable. Together, our studies demonstrate that platelet-targeted gene therapy is a promising approach for the treatment of hemophilia A and hemophilia B.

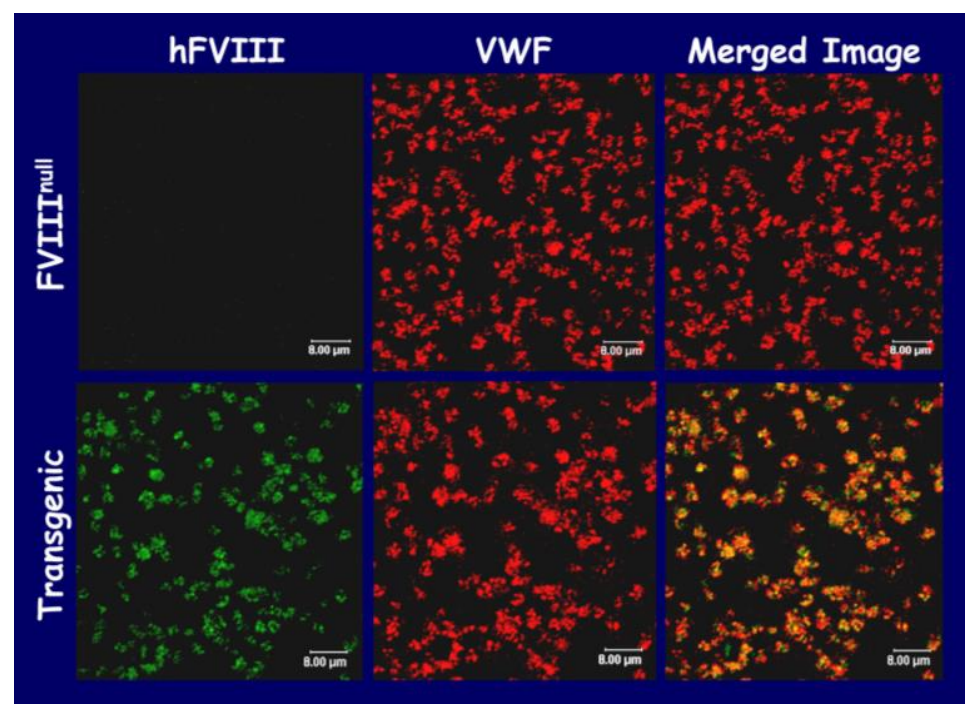

Figure 1. Immunofluorescent confocal microscopy shows FVIII and VWF colocalization in platelets of 2bF8 transgenic mice [Shi et al. J Clin Invest 2006, 116(7):1974-82]. 


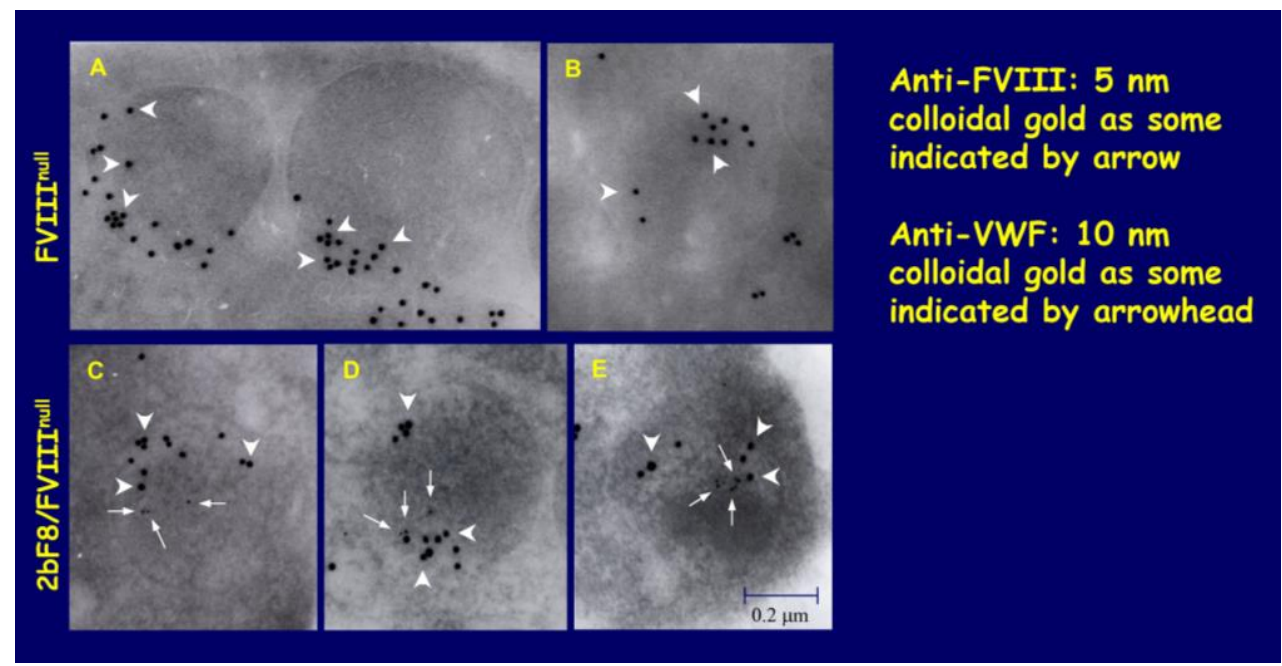

Figure 2. Immunogold electron microscopy confirmed FVIII colocalized with VWF in a-granules in the platelets of $2 \mathrm{bF} 8$ transgenic mice [Shi et al. J Clin Invest 2006, 116(7):1974-82].

\section{References}

1. Shi Q, Wilcox DA, Fahs SA, Weiler H, Well CC, Cooley BC, Desai D, Morateck PA, Gorski J, and Montgomery RR. Factor VIII ectopically targeted to platelets is therapeutic in hemophilia A with hightiter inhibitory antibodies. J Clin Invest 2006, 116 (7):1974-1982.

2. Shi Q, Fahs SA, Wilcox DA, Kuether EL, Morateck PA, Mareno N, Weiler H, and Montgomery RR. Syngeneic transplantation of hematopoietic stem cells (HSC) that are genetically modified to express factor VIII (FVIII) in platelets restores hemostasis to hemophilia A mice with pre-existing FVIII immunity. Blood 2008,112 (7):2713-2721.

3. Zhang G, Shi Q, Fahs SA, Kuether EL, Walsh CE, Montgomery RR. Factor IX ectopically expressed in platelets can be stored in $\alpha$-granules and corrects the phenotype of hemophilia B mice. Blood 2010, 116(8):1235-43. PMCID: PMC2938234.

4. Kuether EL, Fahs SA, Cooley BC, Schroeder JA, Chen Y, Montgomery RR, Wilcox DA, and Shi Q. Lentivirus-mediated platelet gene therapy of murine hemophilia A with pre-existing anti-FVIII immunity. J Thromb Haemost. 2012 Aug;10(8):1570-80.

5. Chen Y, Schroeder JA, Kuether EL, Zhang G, and Shi Q. Lentivirus-mediated platelet gene therapy corrects bleeding diathesis and induces humoral immune tolerance in hemophilia B mice. Mol Ther. 2014; 22(1):169-77.

6. Shi Q, Kuether EL, Chen Y, Schroeder JA, Fahs SA, and Montgomery RR. Platelet gene therapy corrects the hemophilic phenotype in immunocompromized hemophilia A mice transplanted with genetically manipulated human cord blood stem cells. Blood 2014, 123(3):395-403.

7. Chen Y, Luo X, Chen J, Schroeder JA, Baumgartner KC, Hu J, and Shi Q. Immune tolerance developed in platelet-targeted FVIII gene therapy is CD4 T cell-mediated. J Thromb Haemost. 2017 Oct;15(10):1994-2004. 